\title{
POŚTA
}

TELEKOMUNIKÁCIE A

ELEKTRONICKY OBCHOD

\section{VYUŽÍVANIE SLUŽIEB E-GOVERNMENTU PROSTREDNÍCTVOM SLOVENSKEJ POŠTY}

\author{
Dominik Laitkep ${ }^{1}$, Simona Jaculjaková ${ }^{2}$, Jana Štofková ${ }^{3}$
}

\begin{abstract}
In the postal services market in Slovakia, Slovak Post a.s. is the main provider of services. Slovak post is undergoing digitization and striving to provide various services for customers with the highest quality and most modern form. Slovak Post also provides egovernment services for its customers as part of its services. The aim of the paper is to find out if a specific group of customers - legal entities are using e-government services at the branches of Slovak Post.
\end{abstract}

Keywords: e-goverment, post services, Slovak Post

\section{Úvod}

Trh poštových a telekomunikačných služieb sa neustále rýchlo vyvíja. Rozvoj je hnaný najmä digitalizáciou a inováciami v oblasti automatizácie, robotizácie či digitalizácie. $Z$ toho vyplýva, že poštový trh má tendenciu rozmachu v oblasti inovácií a poskytovaní nových služieb na poštovom trhu medzi ktoré sa radí aj poskytovanie služieb e-Governmentu.[1]

\section{Teoretické východiská riešenej problematiky}

Službu môžeme všeobecne definovat' ako určitú činnost' alebo schopnost', ktorú môže poskytnút' jedna strana druhej [2] Podl'a Kotlera vnímame službu ako proces, kde sa stretáva poskytovatel' služby a jeho spotrebitel', pričom nemusí dochádzat' k nadobudnutiu určitého vlastníctva. [3]

Verejnú správu je potrebné chápat’ ako službu, ktorú vykonávajú nielen orgány štátnej správy a územnej samosprávy, ale aj orgány záujmovej samosprávy, verejnoprávne subjekty, štátne organizácie a iné zariadenia vykonávajúce spoločensky prospešnú službu. eGovernment je elektronickou formou výkonu verejnej správy pri aplikácii informačno-komunikačných technológií v procesoch výkonu verejnej správy. Medzi hlavné prednosti je možné zaradit' rýchlejšie, spol'ahlivejšie a lacnejšie poskytovanie elektronických služieb vo vzt’ahu k užívatel'om. [4]

Digitálne zručnosti umožňujú l'ud'om vytvárat' a zdiel'at' digitálny obsah, komunikovat', spolupracovat' a riešit' rôzne problémy v spoločnosti. [5] K zručnostiam a praktickému využívaniu eGovernmentu prispieva aj využívanie služieb poštového operátora.

\footnotetext{
${ }^{1}$ Ing. Dominik Laitkep, Fakulta prevádzky a ekonomiky dopravy a spojov, Katedra spojov, Žilinská univerzita v Žiline, e-mail: dominik.laitkep@fpedas.uniza.sk

${ }^{2}$ Ing. Simona Jaculjaková, Fakulta prevádzky a ekonomiky dopravy a spojov, Katedra spojov, Žilinská univerzita v Žiline, e-mail: simona.jaculjakova@fpedas.uniza.sk

${ }^{3}$ prof. Ing. Jana Štofková, CSc., Fakulta prevádzky a ekonomiky dopravy a spojov, Katedra spojov, Žilinská univerzita v Žiline, e-mail: jana.stofkova@fpedas.uniza.sk
} 
Poštové služby predstavujú $\mathrm{v}$ tomto prípade základný prvok sociálneho spojenia obyvatel'stva. Pri pôsobení jednotlivých odvetví na poštový trh dochádza k rýchlym zmenám u poštových služieb. $\mathrm{V}$ jednotlivých poštových službách sa mení tradičný imidž, čo má za dôsledok poskytovanie služieb prostredníctvom moderných poskytovatel'ov, ktorí sú komplexne hospodárskymi poskytovatel'mi, nielen hodnotnejších, ale aj inovatívnejších služieb. [6]

Ďalším prvkom sú elektronické služby, ktoré predstavujú integrované služby s jednotlivými procesmi a technológiami, prostredníctvom ktorých je možné vyriešit' jednotlivé požiadavky zákazníkov. Z definície pojmu elektronických služieb Svetovou poštovou úniou možno chápat' elektronickú službu tak, že elektronické služby sú poskytované iba národným poštovým operátorom. [7] Vo všeobecnosti ale môžeme hovorit' o elektronických službách ako o novom spôsobe vybavenia určitých potrieb prostredníctvom siete Internet.

Elektronizácia v poštovom sektore, konkrétne v Slovenskej pošte a. s. poskytuje využitie služieb Integrované obslužné miesto občana (IOMO) pre právnické osoby (PO) a fyzické osoby (FO) v rôznych prípadoch. IOMO umožňuje ul'ahčené vybavovanie úradných záležitostí akými sú:

\section{Výpis z obchodného registra pre FO/PO}

Výpis z obchodného registra je potrebný:

- pre účely banky, napríklad pri požiadaní o podnikatel'ský úver alebo pri zakladaní podnikatel'ského účtu,

- pri realizovaní zmeny napr. v názve spoločnosti, pri realizovaní zmeny štatutárnych orgánov, spôsobu podpisovania a pod.

- pre účely v oblasti správneho práva a pod.

Spôsob požiadania o Výpis z obchodného registra

Formou osobného požiadania, a to prostredníctvom:

- okresných súdov - obchodný register v SR,

- pracovísk IOMO,

- notára.

Formou elektronického požiadania a to prostredníctvom:

- ústredného portálu verejnej správy.

Výpis z registra trestov pre $\mathrm{FO} / \mathrm{PO}$

Výpis z registra trestov je potrebný:

- pre potreby prijímania zamestnanca do nového zamestnania, ak ide o prácu, pri ktorej sa vyžaduje bezúhonnost'. Týka sa to pracovných pozícií, ktorými sú policajti, hasiči. Taktiež je potrebné takýto výpis predkladat' budúcemu zamestnávatel'ovi v prípade, že si to vyžaduje povaha práce. Týka sa to pracovných pozícií napr. v banke, poist'ovniach, na pošte (napr. poštový doručovatel', priehradkový zamestnanec), o pracovné pozície $\mathrm{v}$ účtovníctve a pod.

- pri udelení živnostenského oprávnenia,

- pri založení spoločnosti (konatel' ako štatutárny orgán musí preukázat' bezúhonnost'),

- pri žiadaní o štátnu dotáciu a pod.

Spôsob požiadania o Výpis z registra trestov

Formou osobného požiadania, a to:

- v obci, ktorá si vedie matriku,

- na adrese Kvetná 12, Bratislava v ktorej sídli Register trestov Generálnej prokuratúry iba $\mathrm{PO}$,

- na pracoviskách IOMO,

- na zastupitel'ských úradov v zahraničí (vel'vyslanectvá, konzuli).

Formou elektronického požiadania, a to: 
- prostredníctvom ústredného portálu verejnej správa, a to pre FO službou Poskytovanie výpisu a odpisu z registra trestov, Výpis z registra trestov v zahraničí alebo pre orgány verejnej moci na portáli overSi.gov.sk

\section{Odpis z registra trestov pre FO}

Odpis z registra trestov je potrebný:

- pre pedagogických a odborných zamestnancov z dôvodu prijatia do zamestnania,

- pri práci v bezpečnostných službách.

Spôsob požiadania o Odpis z registra trestov

Formou osobného požiadania, a to:

- v obciach, ktoré si vedú matriku,

- na generálnej prokuratúre,

- na pracoviskách IOMO.

Formou elektronického požiadania a to:

- prostredníctvom ústredného portálu verejnej správy, a to službou Podanie žiadosti o výpis a odpis $\mathrm{z}$ registra trestov.

Výpis z listu vlastníctva pre FO/PO

Takýto výpis z listu vlastníctva sa používa na vykonávanie jednotlivých úradných záležitostí s orgánmi verejnej správy pri:

- podaní dani z nehnutel'nosti,

- stavebnom povolení,

- prihlásení trvalého bydliska,

- kúpe nehnutel'nosti,

- predaji nehnutel'nosti,

- uzatvorení darovacej alebo zámennej zmluvy,

- prepise majetku,

- požiadaní o hypotéku a to z dôvodu založenia nehnutel'nosti,

- zistení aktuálnej hodnoty majetku a pod.

Spôsob požiadania o Výpis z listu vlastníctva

Formou osobného požiadania sa uskutočňuje:

- na okresných úradoch v SR (katastrálny odbor),

- na pracoviskách IOMO.

Formou elektronického požiadania a to prostredníctvom:

ústredného portálu verejnej správy. [8]

SP, a. s. od 1.1.2016 do 1.11.2020 poskytla celkovo 2609327 takýchto výstupov. Je potrebné podotknút', že SP, a. s. poskytuje tieto služby asistovane, čo znamená, že žiadatel'/splnomocnenec realizuje minimálny počet činností na to, aby daný výstup získal. [9]

\section{Ciel' a metodika}

Ciel'om odborného článku je zistit' spôsob využívania služieb e-governmentu u právnických osôb pričom sme si určili výskumný predpoklad - Viac ako $20 \%$ oslovených respondentov (podnikatel'ských subjektov) využíva služby e-Govenmentu na pobočkách Slovenskej Pošty a. s..

$\mathrm{Na}$ splnenie ciel'a bolo potrebné využit' metódy excerpovania pri štúdiu a využití internetových a knižných zdrojov pre potreby teoretických východísk riešenej problematiky. Taktiež bola využitá metóda kvantitatívneho primárneho výskumu pri elektronickom dopytovaní. Využité boli taktiež metódy ako analýza a matematicko-štatistické metódy pri prezentovaní výsledkov výskumu.

Kvantitatívny primárny výskum bol realizovaný počas roka 2021. Vel'kost' výberovej vzorky bola vypočítaná pomocou vzorca na výpočet malých a stredných súborov z prostredia podnikatel'ských subjektov v priemyselnej výrobe na území Slovenskej Republiky: 


$$
n \geq \frac{N * t_{1-\frac{\alpha}{2}}^{2} * \sigma^{2}}{(N-1) * \Delta^{2}+t_{1-\frac{\alpha}{2}}^{2} * \sigma^{2}}
$$

kde:

$\mathrm{n}$ - predstavuje minimálne vel'kost' vzorky,

$\mathrm{t}_{1-\alpha / 2}$ - predstavuje kritickú hodnotu, určenú z tabuliek,

$\sigma^{2}-$ predstavuje rozptyl vypočítaný zo smerodajnej odchýlky $\longrightarrow \sigma=\sqrt{p^{*}(1-p)}$,

$\mathrm{p}$ - predstavuje variabilitu základného súboru,

$\Delta$ - predstavuje maximálne prípustné rozpätie chýb,

$\mathrm{N}$ - predstavuje vel'kost' základného súboru.

Výpočet:

$$
n \geq \frac{2976 * 1,96^{2 *} 0,5^{2}}{(2976-1) * 0,05^{2}+1,96^{2 *} 0,5^{2}}=340,34 \doteq 341 \mathrm{PO}
$$

Podarilo sa nám získat' 344 odpovedí od respondentov zo skupiny právnických osôb, čím bola naplnená výskumná vzorka.

\section{Výsledky}

Kvantitatívny primárny výskum, ktorý bol realizovaný prostredníctvom dotazníka v ktorého obsahom boli 4 otázky. Pri vypíňaní daného dotazníka boli respondenti oboznámení s problematikou výskumu, ako aj s účelom, $\mathrm{v}$ rámci ktorého bol daný dotazník realizovaný.

Prvou otázkou nášho primárneho výskumu boli roztriedení respondenti podl'a formy podnikatel'ských subjektov. Identifikácia bola určená na právne formy (Obr. 1).

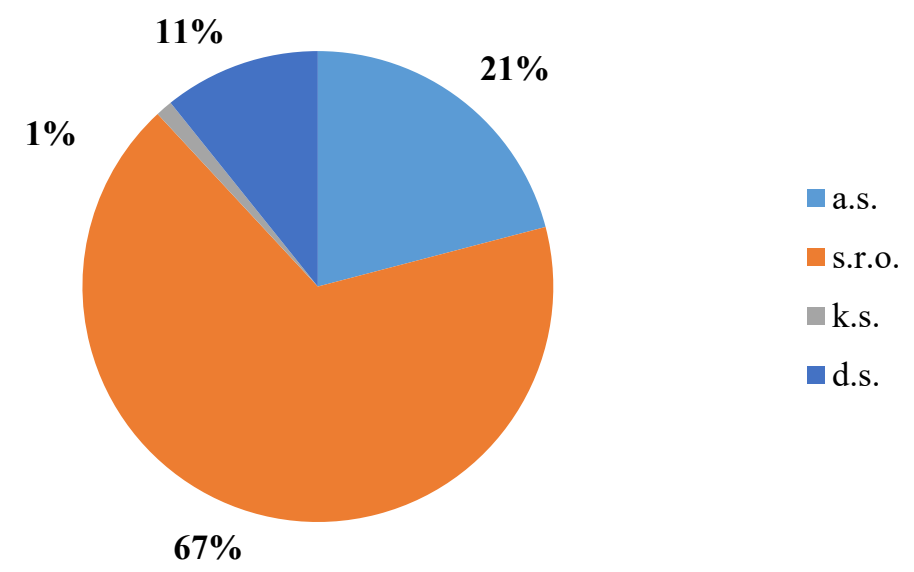

Obrázok 1. Stratifikácia právnických osôb podl’a právnej formy (Zdroj: Autor)

Respondentov tvorili právnické osoby v počte 344 respondentov v zastúpení 72 (21\%) akciové spoločnosti, 231 (67\%) spoločnosti s.r.o., 37 (11\%) d.s. a 4 (1\%) komanditné spoločnosti. 
Druhá otázka roztriedila daných respondentov podl'a počtu zamestnancov (tabul'ka 1).

Tabul'ka 1. Stratifikácia právnických osôb podl'a počtu zamestnancov

\begin{tabular}{|c|c|c|}
\hline $\begin{array}{c}\text { Klasifikácia podnikatel'ského subjektu podl'a } \\
\text { počtu zamestnancov }\end{array}$ & Počet & $\%$ \\
\hline Mirko podniky: od 1 po 9 zamestnancov & 0 & - \\
\hline Malé podniky: od 10 do 49 zamestnancov & 0 & $85 \%$ \\
\hline Stredné podniky: od 50 do 249 zamestnancov & 291 & $15 \%$ \\
\hline Vel'ké podniky: 250 a viac zamestnancov & 53 & $100 \%$ \\
\hline Spolu & 344 & \\
\hline
\end{tabular}

Zdroj: Autor

Z tabul'ky 1 vyplýva, že z 344 podnikatel'ských subjektov, ktoré sa zúčastnili kvantitatívneho primárneho výskumu, bolo s počtom 291 (85\%), najviac zastúpených práve stredných podnikatel'ských subjektov.

Pomocou tretej a zároveň filtračnej otázky sme sa chceli dozvediet', či podnikatel'ské subjekty využívajú služby e-Governmentu (obrázok 2).

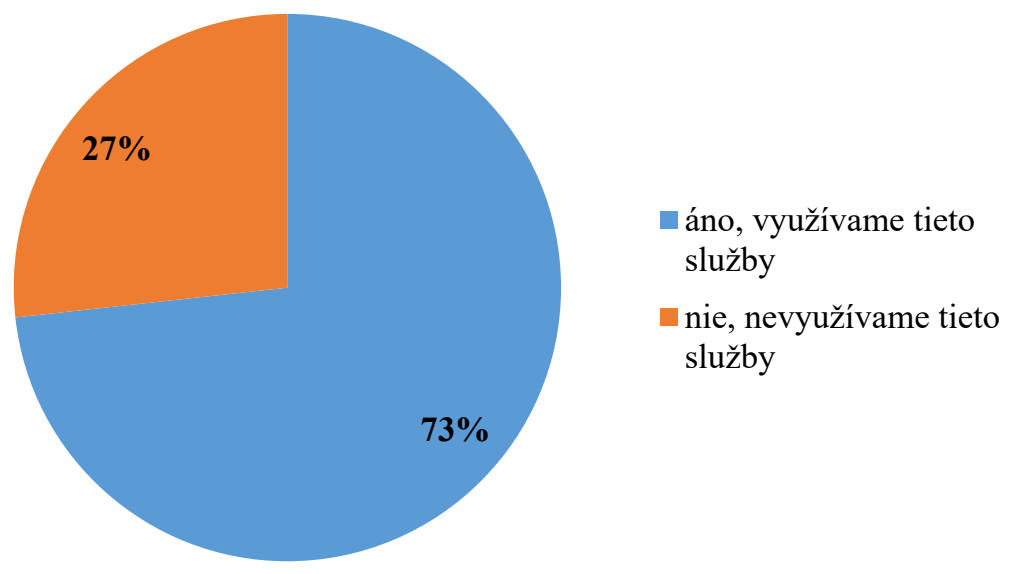

Obrázok 2. Využívanie služieb e-Governmentu, PO (Zdroj: Autor)

Pokladaná otázka bola uzatvorená, čo predstavovalo, že respondenti si mohli vybrat' iba z dvoch možností. Možnost': „áno, využívame tieto služby“ označilo 252 (73\%) podnikatel'ských subjektov. Zápornú možnost' odpovede „nie, nevyužívame tieto služby“ označilo 92 (27\%) podnikatel'ských subjektov.

Pomocou štvrtej, poslednej otázky nášho primárneho výskumu, sme sa chceli dozvediet', ako respondenti využívajú služby e-Govrenmentu. Grafické znázornenie je možné vidiet' na obrázku 3. 


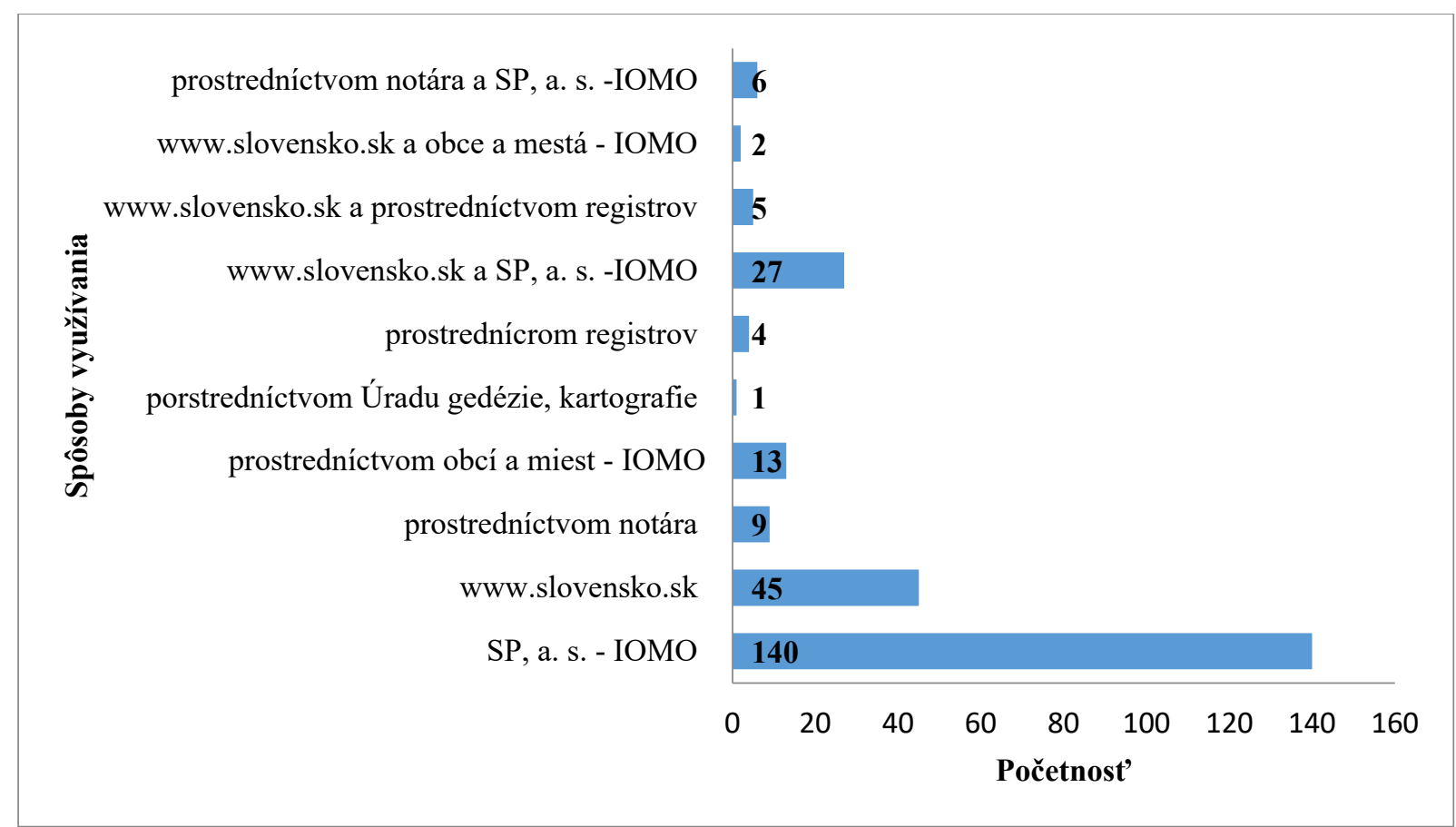

Obrázok 3. Spôsoby využívania služieb e-Governmentu u PO (Zdroj: Autor)

Prostredníctvom tejto otázky sme zistili, akým spôsobom oslovené podnikatel'ské subjekty využívajú jednotlivé služby e-Governmentu. Táto otázka bola uzatvorená s možnost'ou výberu viacerých odpovedí. Z 252 podnikatel'ských subjektov až 140 (56\%) podnikatel'ských subjektov uviedlo, že využíva služby e-Governmentu na pobočkách Slovenskej Pošty, a. s. prostredníctvom IOMO. To znamená, že v prípade, že oslovené podnikatel'ské subjekty potrebujú dané výstupy, využívajú práve služby SP, a. s. prostredníctvom IOMO.

\section{Záver}

Na základe prezentovaného kvantitatívneho primárneho výskumu sme zistili, že podnikatel'ské subjekty na Slovensku využívajú služby e-Govermentu. Náš výskumný predpoklad, že viac ako $20 \%$ oslovených podnikatel'ských subjektov využíva služby eGovernmentu na pobočkách Slovenskej Pošty bol taktiež potvrdený.

Služby e-Governmentu sú u právnických osôb často využívané a nevyhnutné pre ich činnost' v mnohých prípadoch, ako sme ozrejmili v časti teoretické východiská riešenej problematiky. SP, a. s. chce tieto služby nad'alej poskytovat' a nad'alej mat' vedúce postavenie na trhu poštových služieb ale aj v rámci poskytovania nepoštových služieb v oblasti eGovernmentu.

Poskytovanie týchto činností je uskutočnené najmä na základe prudko rozvíjajúcich sa IKT a na základe osobitného rozvoja elektronizácie štátnej správy a služieb e-Governmentu.

\section{Literatúra}

[1] MADLEŇÁKOVÁ, L. Vplyv Industry 4.0. na podmienkach poskytovatel'a univerzálnej poštovej služby. Pošta, telekomunikácie a elektronický obchod.[online]. 2020, vol. 15, no. 2. [cit. 2021-10-17]. Dostupné na internete: <https://ks.uniza.sk/casopis/pdf/II2020/II2020.pdf?fbclid=IwAR1PU6y2_0F38 elkNjZqA7_C4WpqgSXh9QmXWtksZTlp-sNJ $\mathrm{x} 3$ Y txy $8 \mathrm{x} 3 \mathrm{w}>$. ISSN 1336-8281. 
[2] CIBÁKOVÁ, V., CIBÁK, L., RÓZSA, Z. Marketing služieb. Inštitút aplikovaného manažmentu, Trenčín, 2014. 266 s. ISBN 978-80-89600-22-9.

[3] VACULÍK, J., OTTO, I. Analýza mobilných aplikácií vybraných národných poskytovatel'ov poštových služieb. Pošta, telekomunikácie a elektronický obchod.[online]. 2017, vol. 12, no. 1. [cit. 2021-10-17]. Dostupné na internete: $<\mathrm{https}$ ://ks.uniza.sk/casopis/pdf

[4] ŠTOFKOVÁ, J. a kol. Manažment verejnej správy. Žilinská univerzita v Žiline/EDIS, 2019, 200 s. ISBN 978-80-554-1586-4.

[5] JACULJAKOVÁ, S., REPKOVÁ ŠTOFKOVÁ, K. Analysis of basic digital skills of citizens in selected region. 14th annual International Technology, Education and Development Conference, INTED Proceedings, Valencia: IATED, 2020, s. 6141-6149.

[6] HOFACKER, Ch. F., GOLDSMITH, R. E., BRIDGES, E., SWILLEY, E. E-Services: A Synthesis and Research Agenda[online]. [cit. 16.10.2021]. Dostupné na internete: $<$ https://www.researchgate.net/publication/228633756_E-Services_

A_Synthesis_and_Research_Agenda $>$.

[7] Universal Postal Union. Measuring postal e-services development. A globalperspective[online]. [cit. 17. 10. 2021]. Dostupné na internete: $<$ https://hal.archives-ouvertes.fr/hal-01307145/document $>$.

[8] Využívanie služieb e-Governmentu. ÚPVS. [online]. [cit. 2021-17-10]. Dostupné na internete: $<$ https://www.slovensko.sk/sk/titulna-stranka $>$.

[9] Informačný panel IS IOM. [online]. [cit. 17. 10. 2021]. Dostupné na internete: $<$ https://datalab.digital/informacny-panel-is-iom/>.

\section{Grantová podpora}

Príspevok bol spracovaný v rámci riešenia projektu VEGA 1/0518/19. 